\title{
Somatostatin release from dispersed hypothalamic cells: effects of diabetes
}

\author{
S. B. Richardson and S. Twente \\ Departments of Medicine, Veterans Administration and New York University Medical Centers, New York, New York, USA
}

\begin{abstract}
Summary. We examined the release of growth hormone-release inhibiting factor (somatostatin) from dispersed hypothalamic cells obtained from mature diabetic rodents and normal age-matched controls, in an attempt to demonstrate a possible hypothalamic defect which might underlie some of the reported abnormalities in somatotrophic function in diabetes mellitus. Insulinopoenic diabetes was induced by either streptozotocin or alloxan. Somatostatin release from cells from diabetic rats was diminished both basally and after stimulation by membrane depolarisation. Stimulated release was calcium dependent in cells from both normal and diabetic animals. The defect was present in both streptozotocin and alloxan induced diabetes. We also compared hypothalamic somatostatin release from cells obtained from obese hyperinsulinaemic $\mathrm{C} 57 \mathrm{BL} / \mathrm{Ks} \mathrm{db} / \mathrm{db}$ diabetic mice and non diabetic lean litter mates $(\mathrm{db} /-)$. Despite longstanding
\end{abstract}

marked hyperglycaemia, no significant alteration in somatostatin release was apparent. Likewise, starvation of rats for 5 days did not result in significant diminution of somatostatin release. These observations document a defect in hypothalamic somatostatin release in experimentally induced insulinopoenic diabetes, which is not apparent in the $\mathrm{db} / \mathrm{db}$ mouse, suggesting that glucose per se is not responsible. Rather than the anticipated increase in hypothalamic somatostatin release in insulinopoenic diabetes, a reduction in release was observed. These observations are compatible with the hypothesis that increased hypothalamic somatostatin release is not responsible for abnormal growth hormone secretion in this model.

Key words: Somatostatin, hypothalamus, diabetes, streptozotocin.
We became interested in studying hypothalamic function in diabetes mellitus because of reports documenting abnormalities in pituitary function in uncontrolled diabetes. The association between secondary amenorrhea and uncontrolled diabetes was well recognised prior to the therapeutic use of insulin [1]; and secondary hypogonadism has been reported in the diabetic Chinese hamster [2] and the diabetic $\mathrm{db} / \mathrm{db}$ mouse [3]. However, there are conflicting data with regard to pituitary and circulating growth hormone (GH) levels in diabetes. There is considerable evidence that basal, $24 \mathrm{~h}$-integrated and stimulated serum GH levels are elevated in patients with uncontrolled diabetes $[4,5]$ and that control of diabetes can bring return of $\mathrm{GH}$ levels to normal [6].

In rodents, there are reports of increased pituitary $\mathrm{GH}$ concentration in $\mathrm{db} / \mathrm{db}$ obese diabetic mice [7], and of an increase in the number of pituitary somatotrophs in the diabetic Chinese hamster [8]. However, a depression in the amplitude of pulsatile GH secretion in the insulinopoenic streptozotocin (STZ) and BB rat has been documented $[9,10]$. No change in pituitary GH concentration has also been reported in the STZ diabetic rat [9], while the insulinopoenic BB rat demonstrated a reduction in pituitary GH [10].

In an attempt to explain these alterations in pituitary and circulating GH concentrations, a number of investigators have examined hypothalamic function in diabetes. While no reports of growth hormone-releasing hormone levels are available, it has been reported that there is no change in the hypothalamic concentration of somatostatin (SRIF) in the STZ rat [11] and no change $[12,13]$ or a slight increase in the hyperinsulinaemic diabetic $\mathrm{db} / \mathrm{db}$ mouse [14]. However, Tannenbaum was able to restore normal GH ultradian rhythmicity in insulinopoenic STZ rats by the systemic administration of SRIF antiserum [9], leading her to suggest that SRIF was the likely cause of diminished $\mathrm{GH}$ secretion. It might thus seem reasonable to anticipate an elevation in the hypothalamic release of SRIF in the STZ rat.

We can measure radioimmunoassayable SRIF re- 
lease from dispersed hypothalamic cells obtained from adult rats and mice [15-18]. Employing this in vitro approach, we have examined hypothalamic SRIF release in three rodent models of diabetes (1) the insulinopoenic STZ rat, (2) the alloxan (ALL) insulinopoenic rat [19] and (3) the hyperinsulinaemic C57 BL/Ks db/db diabetic mouse [20]. SRIF release from hypothalamic cells obtained from diabetic animals and age-matched non-diabetic control rats was measured $24 \mathrm{~h}$ after dispersion. During a $1-\mathrm{h}$ incubation SRIF was quantitated basally, and after stimulation by the membrane depolarising agent, ouabain, which inhibits $\mathrm{Na}^{+} / \mathrm{K}^{+}$ATPase.

\section{Materials and methods}

\section{Animals}

Groups of 200-300 g male Sprague-Dawley rats were injected with STZ $65 \mathrm{mg} / \mathrm{kg}$ in sodium citrate buffer pH 4.5 i.p., or with ALL $200 \mathrm{mg} / \mathrm{kg}$ in Hanks solution s.c., in order to induce insulinopoenic diabetes. Age-matched male control rats were injected with vehicle alone. After treatment, rats had free access to both rat chow and water. Obese, hyperphagic $\mathrm{C} 57 \mathrm{BL} / \mathrm{Ks} \mathrm{db} / \mathrm{db}$ mice with moderate diabetes and their lean non diabetic litter mates were also studied after unrestricted food and water intake. $250-300 \mathrm{~g}$ male Sprague-Dawley rats were starved for 5 days, with free access to water, in order to assess the effect of starvation on hypothalamic SRIF release.

\section{Hypothalamic cell dispersion}

Details of the methodology, validation and cell viability have been reported in detail [15-18]. Groups of age-matched control and diabetic rats were killed on the same day by decapitation at 10.00 hours. Likewise, mice were killed by cervical hyperextension and rapid decapitation. Hypothalamic fragments from each experimental group of animals, identified as previously [15-18], were rapidly removed in fragments with curved iris scissors and pooled in ice cold Hanks BSS. Cells from control and diabetic animals were dispersed concomitantly in Hank's solution containing collagenase Type II $5 \mathrm{mg}$ / $\mathrm{ml}$, heat inactivated fetal calf serum (HIFCS) $6 \%$, penicillin $100 \mu \mathrm{U} /$ $\mathrm{ml}$, and streptomycin $100 \mu \mathrm{g} / \mathrm{ml}$ at $37{ }^{\circ} \mathrm{C}$. After triturating cells 3-4 times, using a $5 \mathrm{ml}$ polystyrene pipette, dispersion was completed within 20-30 min. Cells were washed and resuspended in CMRL1066 medium with glutamine containing HIFCS 6\%, hydroxyethyl piperazine-ethane sulphonic acid (HEPES) $20 \mathrm{mmol} / 1$, penicillin, streptomycin and bacitracin $6 \mathrm{mg} \%$ in $75 \mathrm{~cm}^{2}$ culture dishes. They were incubated for $24 \mathrm{~h}$ in a humidified atmosphere of $95 \%$ air $/ 5 \%$ $\mathrm{CO}_{2}$ at $37^{\circ} \mathrm{C}$. Cells were easily dislodged by gentle shaking, suspensions were centrifuged at $1000 \mathrm{rpm}$ for $7 \mathrm{~min}$ (Sorvall GLC) and supernatants removed. Cells were resuspended and $200 \mu \mathrm{l}$ aliquots containing cells derived from $1 / 5$ rat hypothalamus or $1 / 3$ mouse hypothalamus were incubated in $1 \mathrm{ml}$ of Hanks solution with HEPES $20 \mathrm{mmol} / 1$ and $6 \mathrm{mg} \%$ bacitracin, with or without test substances, for $1 \mathrm{~h}$ at $37^{\circ} \mathrm{C}$ in $12 \times 75 \mathrm{~mm}$ glass culture tubes. Supernatants were removed after centrifugation at $1000 \mathrm{rpm}$ for $7 \mathrm{~min}$ and assayed immediately or frozen at $-20^{\circ} \mathrm{C}$. Results are expressed as pg/hypothalamus and the number of replicate tubes per experimental group was 5 . No differences in cell number between control and diabetic hypothalami were observed, thus the number of cells per tube were always constant when comparing controls vs diabetics. We have previously documented remarkable consistency in cell yield $[15,18]$. To derive actual SRIF content per culture tube, results expressed as pg/ HT should be divided by 5 for rat cells and by 3 for mouse cells.
SRIF RIA. The SRIF RIA employs a well characterised and highly specific first antibody at a final concentration of $1: 200,000$, as described previously. Goat anti-rabbit gamma globulin was used as second antibody and assay sensitivity was $1 \mathrm{pg}$, intra-assay variation was $4 \%$, and interassay variation was $12 \%$ [21]. The antibody recognises SRIF-14 and -28 on an equimolar basis.

Tissue extraction. Hypothalamic tissue was removed, weighed, homogenised and extracted in $2 \mathrm{~mol} / \mathrm{l}$ acetic acid using a polytron homogeniser and boiled for $5 \mathrm{~min}$. Extracts were centrifuged at $3000 \mathrm{rpm}$ (Sorvall GLC) for $30 \mathrm{~min}$ and supernatants were lyophilised. Pancreata were extracted in the same manner.

Glucose was measured in trunk blood by the O-toluidine method (Sigma).

${ }^{32}$ p incorporation into cellular phospholipids was performed as previously described [15]. Three million cells were incubated with $20 \mu \mathrm{Ci}$ of ${ }^{32} \mathrm{Pi}$ in DMEM for $18 \mathrm{~h}$. After concentration and extraction with chloroform: methanol: water $2: 1: 0.75$, cellular phospholipids were evaporated, redissolved in chloroform: methanol $2: 1$ and chromatographed on silica gel, as previously reported.

Other materials. Hanks solution and CMRL-1066, HIFCS, HEPES, and penicillin/streptomycin were obtained from the Grand Island Biological Co. (Grand Island, NY, USA). Synthetic cyclic 1-14 SRIF, Tyr ${ }^{1}$-SRIF and 1-28 SRIF were obtained from Beckman Instruments (Palo Alto, Calif, USA). Bacitracin, veratridine, streptozotocin were obtained from Sigma Chemical Corp. (St.Louis, Mo, USA). Verapamil $\mathrm{HCl}$ was obtained from Knoll Pharmaceuticals (Whippany, NJ, USA) and was stored frozen in dimethylsulfoxide. Alloxan was obtained from Eastman Kodak Co. (Rochester, NY, USA) and collagenase type II from Worthington Biochemicals (Freehold, NJ, USA). Male C57 BL/Ks db/db and $\mathrm{db} /-$ mice were obtained froms Jackson Labs (Bar Harbor, Me, USA).

\section{Statistical analysis}

Statistical analysis employed Student's t-test.

\section{Results}

\section{Viability of Hypothalamic cells}

As assessed by vital staining with trypan blue and subsequent cell counts under light microscopy, no differences in cell number or viability $(>95 \%)$ were noted between control, STZ or ALL diabetic or starved rat hypothalamic cells. Incorporation of ${ }^{32} \mathrm{Pi}$ into phosphatidyl-choline and inositol were unchanged at $112 \pm 7$ and $101 \pm 7 \%$, respectively, of control, in cells obtained from 14 day STZ diabetic rats $(n=3$ per group).

\section{Hypothahalamic SRIF content}

As shown in Table 1, no significant differences were noted in hypothalamic SRIF concentration between normal rats and diabetic rats at 1,2 or 4 weeks after the induction of diabetes with STZ. However at 2 weeks, total SRIF content was significantly higher $(p<0.05)$ in the STZ group although at 4 weeks this small increase was not significant. Exogenous SRIF recovery was $92 \%$ after tissue extraction. 
Table 1. Hypothalamic somatostatin tissue levels in normal and streptozotocin rats

\begin{tabular}{llrlll}
\hline Duration of diabetes & Glucose (mmol/1) & Hypothalamus (wt in mg) & $\begin{array}{l}\text { SRIF content } \\
\text { (ng/fragment) }\end{array}$ & $\begin{array}{l}\text { SRIF } \\
\text { concentration } \\
(\mathrm{ng} / \mathrm{mg})\end{array}$ \\
\hline 1 week & Normal & $7.4 \pm 0.2$ & $22.9 \pm 2.1$ & $25.4 \pm 3.1$ & $1.1 \pm 0.1$ \\
& STZ & $22.4 \pm 2.4$ & $17.6 \pm 1.3^{\mathrm{a}}$ & $23.8 \pm 4.6$ & $1.3 \pm 0.2$ \\
\multirow{2}{*}{ 2 weeks } & Normal & $5.7 \pm 0.8$ & $21.6 \pm 2.7$ & $18.8 \pm 2.3$ & $0.8 \pm 0.1$ \\
& STZ & $20.9 \pm 2.1$ & $23.6 \pm 2.5$ & $30.3 \pm 3.2^{\mathrm{a}}$ & $1.28 \pm 0.25$ \\
4 weeks & Normal & $6.6 \pm 0.2$ & $17.2 \pm 2.3$ & $16.9 \pm 2.2$ & $0.98 \pm 0.17$ \\
& STZ & $24.7 \pm 1.4$ & $21.8 \pm 1.9$ & $20.9 \pm 1.8$ & $0.9 \pm 0.14$ \\
\hline
\end{tabular}

Values are given as mean \pm SEM and the number of rats in each group was 5 . Hypothalamic somatostatin (SRIF) concentrations did not significantly differ at any time point, but hypothalamic SRIF content was significantly higher only at 2 weeks vs control values. ${ }^{\mathrm{a}} p<0.05$ vs normal)

Table 2. Effects of streptozotocin on hypothalamic SRIF release

\begin{tabular}{rlllc}
\hline Days post STZ & \multirow{2}{*}{$\begin{array}{l}\text { Serum glucose } \\
(\mathrm{mmol} / \mathrm{l})\end{array}$} & \multicolumn{2}{l}{ SRIF release (\% control) } \\
\cline { 3 - 5 } & & \multicolumn{2}{l}{ basal } & ouabain \\
\hline 6 & $(n=4)$ & $22.3 \pm 5$ & $117 \pm 12$ & $96 \pm 4$ \\
7 & $(n=5)$ & $18.2 \pm 5$ & $82.3 \pm 8$ & $80 \pm 4$ \\
8 & $(n=5)$ & $22.7 \pm 1$ & $87.3 \pm 6$ & $102 \pm 3$ \\
9 & $(n=5)$ & $30 \pm 2$ & $93.9 \pm 9$ & $102 \pm 3$ \\
10 & $(n=5)$ & $21.2 \pm 2$ & $59 \pm 14$ & $85 \pm 3$ \\
10 & $(n=5)$ & $19.6 \pm 2$ & $51.8 \pm 6$ & $64 \pm 6$ \\
13 & $(n=7)$ & $25.9 \pm 1$ & $71 \pm 5$ & ND \\
15 & $(n=2)$ & $28.3 \pm 4$ & $73.9 \pm 7$ & $88 \pm 3$ \\
29 & $(n=5)$ & $27.5 \pm 2$ & $66 \pm 6$ & $83 \pm 6$ \\
35 & $(n=2)$ & $30.5 \pm 4$ & $67.7 \pm 5$ & $63 \pm 3$ \\
Pooled values & & $77 \pm 6$ & $85 \pm 5$ \\
& & $(p<0.005$ vs & $(p<0.01)$ \\
\hline
\end{tabular}

Rats were treated with STZ $65 \mathrm{mg} / \mathrm{kg}$ intraperitoneally and SRIF release from dispersed hypothalamic cells was quantitated at 6-35 days post STZ and compared with release from separate groups of controls at each interval. The number of rats surviving post STZ is given in parentheses and glucose and SRIF values are presented as mean $\pm S E M$ values. In order to pool data from different experiments $(n=10)$, SRIF release was calculated as $\%$ of control and results subjected to arcsine transformation. Ouabain $(100 \mu \mathrm{mol} /$ 1) stimulated SRIF release was examined in 9 experiments and again pooled SRIF release, expressed as \% control, after STZ was significantly depressed. $(\mathrm{ND}=$ not done)

Table 3. Effects of alloxan on hypothalamic SRIF release

\begin{tabular}{cll}
\hline Days post ALL & $\begin{array}{l}\text { Serum glucose } \\
(\mathrm{mmol} / 1)\end{array}$ & $\begin{array}{l}\text { SRIF release } \\
(\% \text { control })\end{array}$ \\
\hline $6(n=3)$ & $19.5 \pm 4$ & $83 \pm 8$ \\
$15(n=6)$ & $11.4 \pm 2$ & $76.4 \pm 5$ \\
$15(n=5)$ & $22.4 \pm 1$ & $86.9 \pm 2$ \\
Pooled values & & $82.1 \pm 3(p<0.002)$
\end{tabular}

Alloxan induced diabetes was also associated with a decrease in hypothalamic SRIF release when compared to release from control cells

\section{Hypothalamic SRIF release}

SRIF release from hypothalamic cells obtained from rats with STZ diabetes was studied at intervals of 6 days to 35 days after STZ administration. Representative experimental results are depicted in Figure 1,

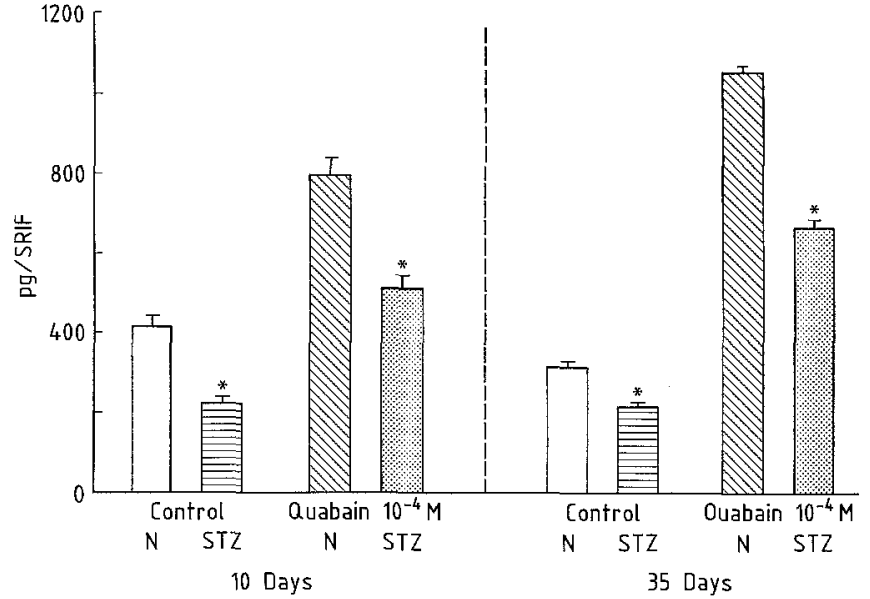

Fig. 1. Hypothalamic SRIF release from dispersed hypothalamic cells is plotted on the vertical axis. Mean $\pm S E M$ values are calculated as pg SRIF per HT (hypothalamic equivalent of cells) and since each culture tube contains cells derived from $1 / 5 \mathrm{HT}$, actual values are $20 \%$ of plotted values. The number of tubes per experimental variable is 5 and at 10 days post STZ (left panel), the numbers of normal and STZ rats were both 5 , whereas at 35 days (right panel) they were 5 and 2 respectively. SRIF release from hypothalamic cells after STZ induced diabetes were significantly lower basally and in response to ouabain stimulation at both 10 and 35 days $(* p<0.001)$

which shows SRIF release at 10 and 35 days post STZ. Pooled data from ten separate experiments are presented in Table 2. This tabulated data shows a statistically significant reduction $(p<0.005)$ in SRIF release after STZ treatment. Significant diminution in stimulated SRIF release after STZ treatment was also observed as presented in Table $2(p<0.01)$.

In order to exclude an effect specific to STZ, we also studied the effects of ALL induced diabetes on hypothalamic SRIF release. As shown in Table 3, at 6 and 15 days, reductions in SRIF release were observed after ALL treatment.

Calcium dependence of ouabain stimulated SRIF release was demonstrated in both normal and diabetic groups by significant inhibition to an equal degree of stimulated release by the calcium channel blocker, verapamil $50 \mu \mathrm{mol} / 1$ or by incubation in calcium-free medium respectively (not shown). 


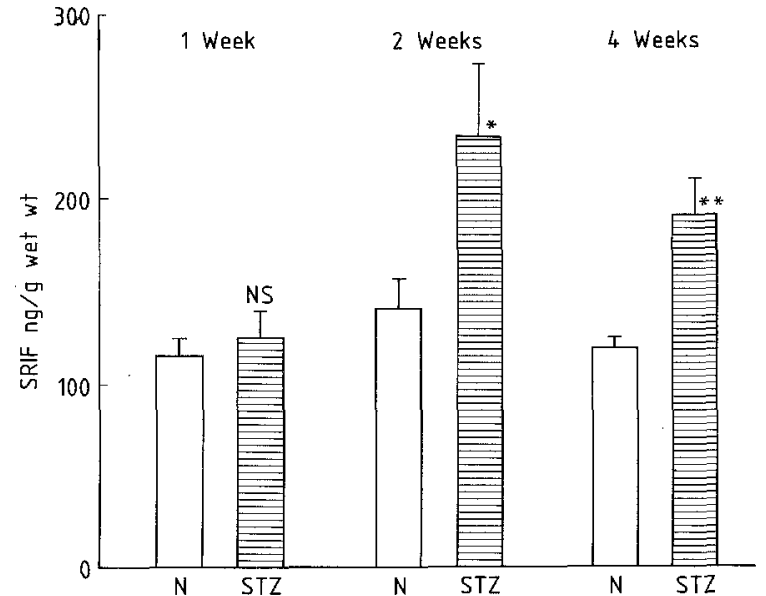

Fig. 2. Pancreatic SRIF concentrations: effects of streptozotocin. Pancreatic SRIF concentrations were measured after 1,2 or 4 weeks of diabetes (respective glucose values were $22.4 \pm 2.4,21 \pm 2$ and $24.7 \pm 1.4 \mathrm{mmol} / \mathrm{l})$ and compared to controls. Significant increases were observed after 2 and 4 weeks. ${ }^{*} p<0.05,{ }^{* *} p<0.005$

Table 4. SRIF release from mouse hypothalamic cells

\begin{tabular}{lll}
\hline Age (days) & $\mathrm{db} /-$ & $\mathrm{db} / \mathrm{db}$ \\
\hline 55 & $\mathbf{1 2 5 \pm 3 6}$ & $118 \pm 33$ \\
85 & $\mathbf{1 2 0 \pm 1 2}$ & $122 \pm \mathbf{1 2}$ \\
123 & $120 \pm 5$ & $135 \pm \mathbf{1 5}$ \\
\hline
\end{tabular}

SRIF release from dispersed hypothalamic cells from diabetic (db/ db) mice (mean glucose $23.6 \pm 2 \mathrm{mmol} / 1$ ) and their non diabetic littermates $(\mathrm{db} /-)$ was compared at various ages. Mean $\pm S E M$ values are expressed as $\mathrm{pg} /$ hypothalamic equivalent of cells. There were 5 mice per group and the number of tubes per point was also 5. No significant differences between diabetic and non-diabetic mice were observed

In an attempt to determine possible mechanisms of this diminution in SRIF release we examined the direct effects of ALL, B-hydroxybutyrate and glucose. SRIF release in the presence of 0.1 and $1 \mathrm{mmol} / 1$ B-hydroxybutyrate was $848 \pm 40$ and $692 \pm 36 \mathrm{pg} / \mathrm{HT}$, respectively, compared to $772 \pm 68 \mathrm{pg} / \mathrm{HT}$ in the controls (NS). In a separate experiment, raising the medium glucose from 5.6 (control) to $22 \mathrm{mmol} / 1 \mathrm{did}$ not affect SRIF release $(440 \pm 17$ vs $416 \pm 44 \mathrm{pg} / \mathrm{HT}$ respectively) nor did the addition of $1 \mathrm{mmol} / \mathrm{l}$ ALL $(428 \pm 32 \mathrm{pg} / \mathrm{HT}$ or $0.1 \mu \mathrm{mol} / \mathrm{l}$ pork insulin $(436 \pm 39 \mathrm{pg} / \mathrm{HT})$. STZ was not tested because of the acid nature of the citrate vehicle employed in STZ administration.

In one experiment, rats were treated with insulin in order to distinguish between effects of insulinopoenic diabetes and a toxic effect of STZ. Diabetes was induced with STZ and three rats, which were positive for urine glucose, were treated with insulin from day 7 until killed 8 days later. Pork U-100 NPH insulin was administered at a dose of $6 \mathrm{U}$ subcutaneously daily. Subsequent numbers represent mean $\pm S E M$ values. Weight gain was $96 \pm 8 \mathrm{~g}$ in normal animals $(n=6)$, $41 \pm 9 \mathrm{~g}$ in insulin-treated diabetic rats and untreated diabetic rats gained no weight $(n=2)$. Serum glucose in the normal animals was $7.4 \pm 3$, in untreated diabetic rats it was $28.3 \pm 2.6$ and $4.8 \pm 1.3 \mathrm{mmol} / \mathrm{l}$ in the insu- lin-treated group. SRIF release from cells in the insulin-treated group was $176 \pm 17 \mathrm{pg} / \mathrm{HT}$, slightly lower than in the STZ group $(238 \pm 16 \mathrm{pg} / \mathrm{HT})$ vs $322 \pm$ $44 \mathrm{pg} / \mathrm{HT}$ in the non diabetic control group, $(p<0.01)$, indicating that insulin treatment under these conditions did not normalise the defect in SRIF release.

As intracellular starvation is a prominent feature of uncontrolled insulinopoenic diabetes, we examined the effect of starvation on in vitro hypothalamic SRIF release. Groups of five male Sprague-Dawley rats were starved for 5 days and received tap water ad libitum. In four experiments, SRIF release was $86 \pm 8,97 \pm 6$, $100 \pm 2$ and $106 \pm 4 \%$ of control values. Pooled values were $97.3 \pm 5 \%$ of control, which were not significantly different from the fed rats $(p=0.3)$.

The last experimental groups of animals studied were obese diabetic $\mathrm{db} / \mathrm{db}$ mice and their non-diabetic lean littermates. Studies were performed at 55, 85 and 123 days of age, when the animals were still massively obese and at which time hyperinsulinaemia would still be expected [20]. As shown in Table 4, no changes in SRIF release were demonstrated in control vs diabetic hypothalamic cells, suggesting that hyperglycaemia per se is not responsible for the diminution in SRIF release observed in the insulinopoenic diabetic rats studied. It should be pointed out that glucose levels in the diabetic mice $(23 \pm 2 \mathrm{mmol} / \mathrm{l})$ were similar to those observed in the ALL and STZ diabetic rats.

\section{Discussion}

This report documents a reduction in SRIF release from dispersed hypothalamic cells obtained from rats with experimentally induced insulinopoenic diabetes. The defect was not apparent at 6 days after STZ treatment but was evident at subsequent time points up to 35 days following the induction of diabetes. No change in hypothalamic SRIF content was observed at 1 week post STZ treatment but at 2 weeks a small but significant increase in SRIF content vs normal controls was noted and at 4 weeks, content was slightly higher, but not at levels which were statistically significant. This latter observation is at odds with previous reports documenting no change in hypothalamic SRIF and the reasons for these discrepancies are unclear [11]. Also of note, we observed no increase in pancreatic SRIF concentration at 1 week, whereas at 2 weeks and 4 weeks there was significant increase after STZ (Fig. 2), underscoring the possible importance of temporal changes in SRIF related to the course of insulinopoenic diabetes.

Treatment with insulin failed to reverse the observed defect in SRIF release from cells obtained from rats with STZ induced diabetes. However, we cannot state categorically that the hypothalamic defect represents a toxic effect of STZ since rats which were treated with insulin gained significantly less weight than controls and displayed significantly lower glucose levels at the time of killing. We have noted extreme diffi- 
culty in normalising glucose levels in STZ diabetic rats (unpublished observations).

While Berelowitz et al. [22] and Lengygel et al. [23] have reported an inhibitory effect of glucose of SRIF release from hypothalamic fragments, such effects are not observed in dispersed adult hypothalamic cells [15]. Since these cells do respond by releasing thyrotropin releasing hormone but not SRIF on exposure to 2 deoxy-D-glucose [24], we feel that the lack of SRIF response to changes in glucose relates to the fact that adult dispersed cells do not contain interneuronal connections and that actions of glucose may not represent direct effects on SRIF neurons. We were unable to demonstrate any effect of glucose, pork insulin, ALL or B-OH-butyrate on SRIF release from normal rat cells over a $1 \mathrm{~h}$ incubation.

It is conceivable that glucose or B OH-butyrate might be responsible for the decrease in SRIF reiease after STZ or ALL treatment, but the lack of any observed defect in hyperinsulinaemic $\mathrm{db} / \mathrm{db}$ mice with equivalent levels of hyperglycaemia, makes a direct effect of glucose per se unlikely. However, it is also conceivable that the mild glucose intolerance manifested by lean non diabetic littermates of obese $\mathrm{db} / \mathrm{db}$ diabetic mice might be capable of inducing the same hypothalamic defect [25]. GH secretion in mice has not been well characterised and other species-related differences may be relevant [7-14].

Starvation did not elicit the hypothalamic defect that was observed after STZ or ALL, suggesting that it was not responsible for reduced SRIF release. Again, it must be cautioned that the defect was not obvious until after 6 days post treatment with STZ. Fasting for a period up to 5 days may have been insufficient to cause intracellular starvation and thus to elicit any potential changes in hypothalamic function, as assessed by our in vitro methods. Berelowitz et al. [26] and Tannenbaum et al. [27] observed no significant alteration in hypothalamic SRIF content after starvation for $72 \mathrm{~h}$, although Tannenbaum noted diminished GH secretion but increased pituitary GH concentration [27]. Their observations do suggest qualitative similarities in altered SRIF-GH regulation in fasted and STZ diabetic rats.

STZ induced diabetes has been associated with a number of abnormalities in CNS and endocrine related functions. For example, diminished hypothalamic glucose transport units [28], catecholamines [29], LHRH [30] and B-endorphin [31] have been reported in STZ diabetes. B-endorphin levels in the neurointermediate lobe were not normalised by insulin treatment, but the authors of this report caution against interpreting these data definitively as an effect of STZ as opposed to an effect of STZ induced diabetes [32]. In the same model, reduced CNS adenyl cyclase activity [33] and dopaminergic function [34] have also been reported.

While it is difficult to pinpoint the likely mechanism responsible for the hypothalamic defect in experi- mental insulinopoenic diabetes, a number of alterations in SRIF metabolism have been described in response to STZ induced diabetes. Thus hypersomatostatinaemia [35], increased pancreatic [36] and gut SRIF [37] have been documented. Our observations, certainly suggest that the hypothalamus may not be contributory as a source of additional SRIF secretion in STZ diabetes. As mentioned in the introduction, Tannenbaum was able to restore the diminished amplitude GH secretory peaks observed in STZ diabetic rats by the administration of SRIF antiserum to immunoneutralise circulating SRIF [9]. Our observations provide indirect support for the suggestion that SRIF derived from extra hypothalamic sources might be capable of modulating GH secretion, as hypothesised by Tannenbaum [9].

Both GH and somatomedin C have feedback effects on GH secretion and stimulate hypothalamic SRIF release [38, 39]. Circulating levels of both GH and somatomedin are diminished in the insulinopoenic diabetic rat $[9,40]$. Thus two possible mechanisms responsible for diminished hypothalamic SRIF release in insulinopoenic diabetes can be put forward; i.e. diminished GH or somatomedin levels, or both, fail to stimulate SRIF release in the normal fashion.

Recently, Peterfreund and Vale [41] and ourselves [18], employing in vitro techniques, and Lumpkin et al. employing in vivo methodology [42], have shown that hypothalamic SRIF secretion is inhibited by SRIF, suggestive of ultrashort-loop feedback. It is thus conceivable that high circulating SRIF levels, derived from extra hypothalamic sites, might result in the inhibition not only of GH secretion, but also of SRIF release from the hypothalamus via a feedback mechanism. However, because of the blood-brain barrier, we cannot be certain that peptides in the systemic circulation might impinge on this feedback loop.

In conclusion, the demonstration of diminished hypothalamic SRIF release in STZ or ALL diabetic rats is more compatible with an effect, rather than a cause, of abnormal GH secretory dynamics in these models. It is also compatible with the hypothesis that peripherally derived SRIF may be capable of modulating GH secretion.

Acknowledgements. This work was supported by Veterans Administration Research Funds. The authors thank Ms. E. Allard for her expert preparation of the manuscript.

\section{References}

1. Williams RH, Porte D, Jr (1974) The pancreas. In: Williams RH (ed) Textbook of endocrinology. Saunders, Philadelphia, pp 502-626

2. Gerris DR, Smith C, Davis D, Diani AR and Gerritsen GC (1982) Morphometric evaluations of the hypothalamic-ovarian axis of the ketonuric, diabetic Chinese hamster: relationship to the reproductive cycle. Diabetologia 23: 275-279

3. Bray GA, York DA (1979) Hypothalamic and genetic obesity in experimental animals: an anatomic and endocrine hypothesis. Physiol Rev 59: 719-809 
4. Hansen AP, Johansen K (1971) Diurnal serum growth hormone levels in poorly and well controlled juvenile diabetics. Diabetes 20: $239-245$

5. Hansen AP (1970) Abnormal serum growth hormone response to exercise in juvenile diabetes. J Clin Invest 49: 1467-1478

6. Merimee TJ, Fitzgerald CR, Gold LA, McCourt JP (1979) Characteristics of growth hormone secretion in clinically stable diabetes. Diabetes 28: 308-312

7. Desjardins C (1969) Pituitary growth hormone and its hypothalamic releasing factor in normal and genetically diabetic mice. Proc Soc Exp Biol Med 130: 1-4

8. Deslex P, Rossi GL (1976) Quantitative evaluation of somatotrophic cells in the adenohypophysis of normal and diabetic male Chinese hamsters. Diabetologia 12: 489-493

9. Tannenbaum GS (1981) Growth hormone secretory dynamics in streptozotocin diabetes: evidence of a role for endogenous circulating somatostatin. Endocrinology 108: 76-82

10. Tannenbaum GS, Colle E, Gurd W, Wannamaker L (1981) Dynamic time-course studies of the spontaneously diabetic BB Wistar rat. Longitudinal profiles of plasma growth hormone, insulin and glucose. Endocrinology 100: 1872-1879

11. Patel YC, Cameron DP, Bankier A, Malaisse-Lagae F, Ravazzola M, Studer P, Orci L (1978) Changes in somatostatin concentration in pancreas and other tissues of streptozotocin diabetic rats. Endocrinology 103: 917-923

12. Dolais-Kitabgi J, LaMarschaud-Brustel Y, Freychet P (1979) Somatostatin in the pancreas and hypothalamus of obese mice. Diabetologia 17: 277-281

13. Makino H, Matsushima Y, Kanatsuka A, Yamamoto M, Kumagai A, Nishimura M (1979) Changes in pancreatic somatostatin constant in spontaneously diabetic mice, as determined by radioimmunoassay and immunohistochemical methods. Endocrinology 104: $243-247$

14. Patel YC, Cameron DP, Stefan Y, Malaisse-Lagae F, Orci L (1977) Somatostatin: widespread abnormality in tissue of spontaneoulsy diabetic mice. Science 198: 930-931

15. Richardson SB, Greenleaf PW, Hollander CS (1983) Somatostatin release from dispersed hypothalamic cells. Effects of membrane depolarization, calcium and glucose deprivation. Brain Res 266: 75-81

16. Richardson SB, Nguyen T, Hollander CS (1983) Dopamine stimulates somatostatin release from perifused rat hypothalamus cells. Am J Physiol (E\&M) 244: E560-566

17. Richardson SB, Twente S (1985) Mouse hypothalamic somatostatin release: roles of calcium and calmodulin. Endocrinology 117: $369-375$

18. Richardson SB, Twente S (1986) Inhibition of rat hypothalamic somatostatin release by somatostatin: evidence for somatostatin ultrashort-loop feedback. Endocrinology 118: 2076-2082

19. Fischer LJ, Rickert DE (1975) Pancreatic islet cell toxicity. CRC Crit Rev Toxicol 231-263

20. Coleman DL (1978) Obese and diabetes: two mutant genes causing diabetes-obesity syndromes in mice. Diabetologia 14: 141-148

21. Richardson SB, Hollander CS, DeLetto RD, Greenleaf PW, Thaw C (1980) Acetylcholine inhibits the release of somatostatin from rat hyothalamus in vitro. Endocrinology 107: 122-129

22. Berelowitz M, Dudlak D, Frohman LA (1982) Release of somatostatin-like immunoreactivity from incubated hypothalamus and cerebral cortex. Effects of glucose and glucoregulatory hormones. J Clin Invest 69: 1293-1301

23. Lengyel AM, Grossman A, Nieuwenhuyzen-Kruseman AC, Ackland J, Rees LH, Besser GM (1984) Glucose modulation of somatostatin and LHRH release from rat hypothalamic fragments in vitro. Neuroendocrinology $39: 31-38$

24. Hollander CS, Richardson S, Ferdinand P, Greenleaf P (1979) Thyrotropin releasing factor secretion from dispersed rat hypothalamic cells is stimulated by potasșium depolarization and glucose deprivation. Proceedings of the Annual Endocrine Society Meeting 426 (Abstract)

25. Molina JM, Premdas FH, Klenck RE, Eddlestone G, Old- ham SB, Lipson LG (1984) The dynamic insulin secretory response of isolated pancreatic islets of the diabetic mouse. Diabetes 33: 1120-1123

26. Shapiro B, Berelowitz M, Pimstone BL, Kronheim S, Sheppard $M$ (1979) Tissue and serum somatostatin-like immunoreactivity in fed, $15 \mathrm{~h}$-fasted and $72 \mathrm{~h}$ fasted rats. Diabetes 28: 182-184

27. Tannenbaum GS, Rorstad O, Brazeau P (1979) Effects of prolonged food deprivation on the ultradian growth hormone rhythm and immunoreactive somatostatin tissue levels in the rat. Endocrinology 104: 1733-1738

28. Malthaei S, Horuk R, Olefsky JM (1986) Blood-brain glucose transfer in diabetes mellitus: decreased number of glucose transporters at blood-brain barrier. Diabetes 35: 1181-1184

29. Chu PCV, Lin MT, Shian LR, Len SY (1986) Alterations in physiological functions and in brain monoamine content in streptozotocin-diabetic rats. Diabetes 35: 481-485

30. Tesone M, Lodenheim RG, Cheb-Terrab R, Chiauzzi V, Solano A, Podesta E, Charreau EH (1986) Comparison between bioactive and immunoreactive luteinizing hormone $(\mathrm{LH})$ in ovariectomized streptozotocin induced diabetic rats: response to LH-releasing hormone. Endocrinology 119: 2412-2416

31. Gibson MJ, DeNicola AF, Krieger DT (1985) Streptozotocin-induced diabetes is associated with reduced immunoreactive Betaendorphin concentrations in neurointermediate pituitary lobe and with disrupted circadian periodicity of plasma corticosterone levels. Neuroendocrinology 41: 64-71

32. Forman LJ, Marquis DE, Stevens R, Adler R, Vasilenko P (1985) Diabetes induced by streptozotocin results in a decrease in immunoreactive Beta endorphin levels in the pituitary and hypothalamus of female rats. Diabetes 34: 1104-1107

33. Palmer GG, Wilson GL, Chronister RB (1983) Streptozotocin-induced diabetes produces alterations in adenylate cyclase in rat cerebrum, cerebral microvessels and retina. Life Sci 32: 365-374

34. Lozovsky D, Saller CF, Kopin IJ (1981) Dopamine receptor binding is increased in diabetic rats. Science 214: 1031-1033

35. Schusdziarra V, Dobbs RE, Harris, Unger RH (1977) Immunoreactive somatostatin levels in plasma of normal and alloxan diabetic dogs. FEBS Lett $81: 69-72$

36. Patel YC, Weir GG (1976) Increased somatostatin content of islets from streptozotocin diabetic rats. Clin Endocrinol (Oxf) 5: 191-194

37. Berelowitz M, Shapiro B, Pimstone B, Kronheim S (1979) Growth hormone release inhibitory hormone like immunoreactivity in pancreas and gut in streptozotocin diabetes and response to insulin administration. Clin Endocrinol (Oxf) 10: 195-198

38. Berelowitz M, Szabo M, Frohman LA, Firestone S, Chu L, Hintz RL (1981) Somatomedin-C mediates growth hormone negative feedback by effects on both the hypothalamus and pituitary. Science 212: 1279-1281

39. Sheppard MC, Kronheim S, Pimstone BL (1978) Stimulation by growth hormone of somatostatin release from the rat hypothalamus in vitro. Clin Endocrinol (Oxf) 9: 583-586

40. Phillips LS, Young HS (1976) Nutrition and somatomedin II. Serum somatomedin activity and cartilage growth activity in streptozotocin-diabetic rats. Diabetes 25: 516-527

41. Peterfreund RA, Vale WW (1984) Somatostatin analogs inhibit somatostatin secretion from cultured hypothalamus cells. Neuroendocrinol 39: 397-402

42. Lumpkin M, Negro-Vilar A, McCann SM (1981) Paradoxical elevation of growth hormone by intraventricular somatostatin: possible ultrashort-loop feedback. Science 211: 1072-1074

Received: 14 April 1987

and in revised form: 21 September 1987

Dr. Stephen Richardson

Department of Medicine

VA Medical Center

408 First Avenue

New York, NY 10010

USA 